\title{
Consumers' Choice for Vegetable Market Channels in Indonesia
}

\author{
Alim Setiawan Slamet ${ }^{*}, 1,3$ and Akira Nakayasu ${ }^{2}$ \\ ${ }^{1}$ The United Graduate of Agricultural Science, Ehime University, \\ Tarumi 3-5-7, Matsuyama 790-8566, Japan. \\ ${ }^{2}$ Department of Agricultural Economics and Agribusiness, Ehime University, Japan \\ ${ }^{3}$ Department of Management, Bogor Agricultural University, Indonesia \\ Email: alimss@ipb.ac.id*
}

\begin{abstract}
The purpose of this study is to explore consumers' choice for vegetable market channels and to determine the factors which affect their choices. A survey involving 887 respondents was carried out in Jabodetabek area. This study found that the traditional retail formats (e.g., wet market, peddler, and kiosks aka warungs) were the favorable place for vegetable purchasing. The results of the multinomial logit model analysis suggests that consumers' retail format choice is determined by domicile, education level, income level, employment status of women, and purchase frequency. Moreover, other factors that influenced consumer choice is price, quality of product, safety concern, store attributes, easiness \& availability, and brand \& traceability information.
\end{abstract}

Keywords: Consumers' choice, vegetable market channels, multinomial logit analysis, factor analysis, Jabodetabek

\section{INTRODUCTION}

In the past decades, Indonesia has experienced a rapid expansion of modern retail formats such as supermarkets, hypermarkets and convenience stores (Dyck et al., 2012). It has brought a better quality product, competitive price, more convenience, and safer (Suryadarma et al., 2010). The groceries market were gradually replaced the role of traditional retail market formats, since it provides vary merchandise choices and very organized shop (Chamhuri and Batt, 2013).

The diffusion of modern retail market in the developing countries has been investigated by several researchers (Goldman and Hino, 2005; Goldman, 2001; Reardon and Berdegué, 2008) and summarized as there are three diffusion components: across geography (urban to rural), across socioeconomic segments (high and middle-income to lower income consumers), and by product category (processed to fresh). However, even though in some countries the geographic diffusion is completed (Goldman and Hino, 2005; Maruyama and Trung, 2007), supermarkets have been unable to capture the major share of the fresh fruit and vegetable market due to perceptions of inferior freshness and quality of fruit and vegetables sold at supermarkets; and cultural and social advantages (Kusumawaty et al., 2013).

Our research questions address how far Indonesia has progressed towards modern retail formats and what the determinant factors that affect consumers retail formats choice when purchasing vegetable.

\section{MATERIAL AND METHODS}

\subsection{Data and Measurements}

The data for this study were obtained from 887 respondents through interviews with the people who are responsible for purchasing food for their household using a structured questionnaire. The survey was conducted from February to March 2015 in the Jabodetabek region, which was divided into five zones (Jakarta, Depok, Bogor, Tangerang, and Bekasi). Jabodetabek region was chosen because it represents the most rapid growing of modern retail market in Indonesia.

The questionnaire was divided into two sections. Firstly, the respondents were asked questions about their household's sociodemographic and geographic characteristics (e.g., age, gender, education, marital status, employment status of the women in the 
households, monthly income level, domicile and vegetable purchase frequency).

Secondly, questioning the motives of consumers of the retail market whether they were motivated for purchasing food. We ask respondents where they did usually purchase for vegetable. The respondents were also asked to rank the agreement or the importance of the following statements based on their motives for purchasing food, using a seven-point Likert scale, from $1=$ "if respondents answer strongly disagree/not important at all" to $7=$ "if respondents answer strongly agree/very important”.

\subsection{Methods}

The determinants of consumer choice of retail formats in this study was analyzed at a two-stage process: factor analysis and multinomial logit analysis. First, factor analysis was conducted to reduce the number of variables for vegetable purchasing motives, which involved principal component analysis and varimax rotation. Only factors with an Eigenvalue greater than 1 were extracted. Furthermore, items with a factor loading of 0.5 and above were considered valid items to obtain the rotated factor matrix. To ensure the suitability of conducting a factor analysis, this

Table 1. Summary of factor analysis

\begin{tabular}{|c|c|c|c|}
\hline Factor label & Statements and factor loadings & $\begin{array}{c}\text { Cronbach's } \\
\text { alpha }\end{array}$ & $\begin{array}{c}\text { Variance } \\
\text { explained (\%) }\end{array}$ \\
\hline Quality & $\begin{array}{l}\text { Have a pleasant texture }(0.793) \text {, } \\
\text { Good color }(0.792) \text {, Smells nice } \\
(0.759) \text {, Looks fresh }(0.708), \\
\text { Looks nice in appearance }(0.692) \text {, } \\
\text { Tastes good }(0.674)\end{array}$ & 0.870 & 11.56 \\
\hline Price & $\begin{array}{l}\text { Good value for money }(0.824) \text {, Fit } \\
\text { their budget }(0.793) \text {, Not } \\
\text { expensive }(0.681)\end{array}$ & 0.775 & 7.13 \\
\hline Safety & $\begin{array}{l}\text { Free of dangerous chemicals } \\
(0.821) \text {, Contains no additive } \\
(0.805) \text {, Free of pathogen } \\
\text { microorganisms ( } 0.803) \text {, Contains } \\
\text { no artificial ingredients }(0.776) \text {, } \\
\text { Natural production }(0.591)\end{array}$ & 0.900 & 11.07 \\
\hline $\begin{array}{l}\text { Brand } \\
\text { \&Traceability }\end{array}$ & $\begin{array}{l}\text { Well-known brand (0.869), Brand } \\
\text { has good reputation }(0.851) \text {, } \\
\text { Locally produced }(0.773) \text {, Clear } \\
\text { label }(0.638) \text {, Certification from } \\
\text { reputable institution }(0.626) \text {, } \\
\text { Quality certified }(0.610)\end{array}$ & 0.890 & 10.92 \\
\hline Health & $\begin{array}{l}\text { Keeps me and my family healthy } \\
(0.781) \text {, High in fiber and contains } \\
\text { a lot of vitamins }(0.718)\end{array}$ & 0.857 & 5.89 \\
\hline $\begin{array}{l}\text { Easiness \& } \\
\text { Availability }\end{array}$ & $\begin{array}{l}\text { Easy to get refer to location and } \\
\text { accessibility }(0.734) \text {, Always } \\
\text { available }(0.619)\end{array}$ & 0.777 & 5.49 \\
\hline $\begin{array}{l}\text { Environment } \\
\text { al concerns }\end{array}$ & $\begin{array}{l}\text { Low carbon emissions }(0.865) \text {, } \\
\text { uses environmentally friendly } \\
\text { packaging }(0.845) \text {, efficient use of } \\
\text { resources }(0.835) \text {, environmental } \\
\text { inputs }(0.771)\end{array}$ & 0.925 & 11.27 \\
\hline $\begin{array}{l}\text { Store } \\
\text { attributes }\end{array}$ & $\begin{array}{l}\text { Better service }(0.820) \text {, more } \\
\text { secure }(0.798) \text {, cleaner and more } \\
\text { convenient }(0.756) \text {, more practical } \\
(0.659)\end{array}$ & 0.774 & 7.43 \\
\hline
\end{tabular}

study used the Kaiser-Mayer-Olkin (KMO) test and Bartlett's test of sphericity. In this study, the KMO value is 0.889 and the Bartlett's test of sphericity was statistically significant at the $1 \%$ level.

The internal reliability consistency was tested by the Cronbach's alpha score, which showed that all factors have sufficient internal reliability consistency with the coefficient values from 0.774 to 0.925 . Table 1 shows eight of identification factors, which are: (1) product quality, (2) price, (3) food safety concern, (4) brand \& traceability, (5) health, (6) easiness \& availability, (7) environmental concern, and (8) store attributes. Approximately $70.76 \%$ of the total variant was found in the eight latent factors account.

Second, in order to determine the influential factors in consumers' choice of vegetable retail format, factor loadings extracted from a factor analysis were utilized in a multinomial logit model together with the socio-demographic profiles of the respondents. This model represents an appropriate approach in exploring and explaining the choice process where the choice set consists of more than two alternatives (Greene, 1998). When the dependent variable has nominal responses, one category of the dependent variable is designated as the baseline category.

Multinomial logit model has been used widely in several consumers' preference studies. Goktolga et al. (2006) have used multinomial logit model to analysis factors affecting primary choice of consumers in food purchasing in Turkey. Briz and Ward (2009) have used multinomial logit models to predict probabilities of consumer awareness of organic product in Spain. Tiryaki and Akbay (2010) have applied multinomial logit model to investigate the selected socioeconomic and demographic characteristics of consumers that determine households' fluid milk consumption choices between unprocessed fluid milk, processed fluid milk and non-consumption choices in Turkey. Tobler et al. (2011) investigated consumers' willingness to adopt ecological food consumption behaviors using multinomial logit regression. Janssen and Hamm (2012) 
studied consumer preferences and willingnessto-pay for different organic certification logos in six European countries using multinomial logit model. Kohansal and Firoozzare (2013) have applied multinomial logit model for determining socio-economic factors affecting major choice of consumers in food purchasing.

Formally, the logit model is calculated by using Eq.1, where $X n$ is a vector of all explanatory variables for consumer $n$.

$P\left(y_{n}=i\right)=\frac{\exp \left(X_{n} \beta_{i}\right)}{1+\sum_{j=1}^{J} \exp \left(X_{n} \beta_{j}\right)}$

in addition, $i$ and $j$ represent choice alternatives for choice set $\mathrm{J}$ and $\beta \mathrm{j}$ the parameters estimated by the multinomial logit model.

\section{RESULT AND DISCUSSION}

\subsection{Socio-demographic and retail choice characteristics}

The data show that the age range of respondents was 18-73 years and the average age was 36.55 years. As the survey was conducted towards persons who are responsible of household shopping, the number of female respondents is higher than male respondents ( $88 \%$ females and $12 \%$ males). This is because women have the strongest influence in household buying decisions in Indonesia. A majority of the respondents (71\%) reported that they are married with the average family size 4-5 people, and most of them live in an urban domicile.

In term of education level, the majority of the respondents (46\%) graduated from secondary school, $43 \%$ graduated from tertiary education or higher and $11 \%$ graduated from primary school (9 years). The proportion of employed women in households was determined to be $40 \%$. Sixty-three percent of the households have a monthly income of between 1 million and 5 million rupiah and $27.3 \%$ have a monthly income more than 5 million rupiah. The majority of respondents purchase vegetable every day or almost every day. Table 2 shows the definition and descriptive of socio-demographic variables.

When consumers purchase vegetable for their household, they have a retail format choice. From the Fig. 1, a total $40 \%$ of respondents indicated that they most shop for vegetable at wet markets, $25 \%$ mostly purchased at kiosks/warungs, $17 \%$ mostly shopped at peddlers, $7 \%$ mostly purchased at supermarkets, $6 \%$ mostly shopped at hypermarkets, and only 5\% mostly purchased at minimarket and modern specialty stores. These data suggest that all traditional retail formats counted (88\%) and still preferred as the main choice for the majority of respondents for purchasing vegetable.

Table 2. The sociodemographic characteristics and variables

\begin{tabular}{|c|c|c|c|}
\hline Variables & Definition & Mean & SD \\
\hline Gender & $1=$ female, $0=$ male & 0.88 & 0.328 \\
\hline Age & $\begin{array}{l}\text { Actual age given by the } \\
\text { respondents (years) }\end{array}$ & 36.55 & 11.815 \\
\hline Marital status & $1=$ married, $0=$ single & 0.71 & 0.455 \\
\hline Household size & $\begin{array}{l}\text { Total number of } \\
\text { individuals in household }\end{array}$ & 4.59 & 2.268 \\
\hline Domicile & $\begin{array}{l}1=\text { urban, } 2 \text { = suburban, } 3 \\
=\text { rural }\end{array}$ & 1.55 & 0.57 \\
\hline Education level & $\begin{array}{l}1 \text { = primary education or } \\
\text { lower, } 2 \text { = secondary } \\
\text { education, and } 3 \text { = tertiary } \\
\text { education or higher }\end{array}$ & 2.32 & 0.659 \\
\hline $\begin{array}{l}\text { Employed } \\
\text { women's status }\end{array}$ & $\begin{array}{l}1=\text { working, } 0 \text { = housewife } \\
\text { or unemployed }\end{array}$ & 0.40 & 0.490 \\
\hline Income & $\begin{array}{l}1=<1000,2=1000-3000 \\
3=3000-5000,4=5000- \\
7000,5=>7000 ; \text { per } \\
\text { month (Rp 000) }\end{array}$ & 2.79 & 1.141 \\
\hline $\begin{array}{l}\text { Vegetable } \\
\text { purchasing } \\
\text { frequency }\end{array}$ & $\begin{array}{l}1=\text { once a month, } 2= \\
\text { several times a month, } 3= \\
\text { once a week, } 4=\text { every day } \\
\text { or almost every day }\end{array}$ & 3.65 & 0.654 \\
\hline
\end{tabular}

In order to identify the factors influencing consumers' choice, we combined modern retail types and compare with each of traditional retail formats. In the multinomial logistic regression model, consumer retail formats choice is defined as the dependent variable with the assessment $j=0,1,2$, and 3 for modern markets, kiosks/warungs, wet markets, and peddlers, respectively.

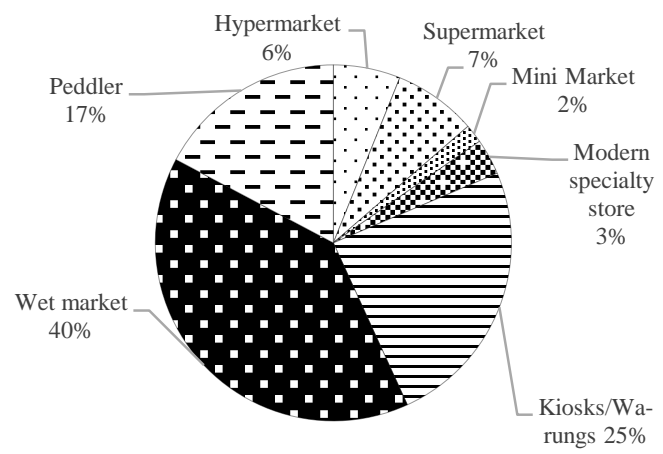

Figure 1. Preferred outlets for purchasing vegetable 
Table 3. Parameter estimates from the multinomial logit model

\begin{tabular}{|c|c|c|c|c|c|c|}
\hline \multirow[t]{2}{*}{ Variable } & \multicolumn{2}{|c|}{$\begin{array}{c}\text { Kiosks/warungs vs. } \\
\text { modern markets }\end{array}$} & \multicolumn{2}{|c|}{$\begin{array}{l}\text { Wet markets vs. } \\
\text { modern markets }\end{array}$} & \multicolumn{2}{|c|}{$\begin{array}{c}\text { Peddlers vs. modern } \\
\text { markets }\end{array}$} \\
\hline & $\beta$ & $\operatorname{Exp}(\beta)$ & $\beta$ & $\operatorname{Exp}(\beta)$ & $\beta$ & $\operatorname{Exp}(\beta)$ \\
\hline Intercept & 0.722 & & -0.186 & & -3.051 & \\
\hline Age & 0.021 & 1.021 & 0.010 & 1.010 & 0.019 & 1.020 \\
\hline Gender & 0.336 & 1.399 & 0.168 & 1.183 & 0.610 & 1.840 \\
\hline Domicile & $0.546^{* *}$ & 1.726 & $0.603 * * *$ & 1.828 & $0.609 * * *$ & 1.838 \\
\hline Marital status & -0.025 & 0.975 & 0.202 & 1.224 & 0.157 & 1.170 \\
\hline Education & $-0.688 * * *$ & 0.502 & -0.159 & 0.853 & 0.146 & 1.157 \\
\hline Household size & -0.087 & 0.917 & 0.006 & 1.006 & -0.009 & 0.991 \\
\hline $\begin{array}{l}\text { Employment status } \\
\text { of women }\end{array}$ & 0.028 & 1.028 & 0.076 & 1.079 & $-0.533 *$ & 0.587 \\
\hline Income & $-0.306 * *$ & 0.736 & -0.174 & 0.840 & $-0.424 * * *$ & 0.654 \\
\hline $\begin{array}{l}\text { Vegetable purchase } \\
\text { frequency }\end{array}$ & 0.205 & 1.227 & 0.088 & 1.092 & $0.520^{* *}$ & 1.683 \\
\hline Product quality & $0.327 * * *$ & 1.386 & 0.129 & 1.138 & 0.078 & 1.081 \\
\hline Price & $0.208^{*}$ & 1.231 & $0.223^{* *}$ & 1.249 & $0.280^{* *}$ & 1.323 \\
\hline Safety & 0.136 & 1.145 & $0.267 * * *$ & 1.306 & $0.242 * *$ & 1.274 \\
\hline $\begin{array}{l}\text { Brand \& } \\
\text { Traceability }\end{array}$ & $-0.942 * * *$ & 0.390 & $-0.530 * * *$ & 0.589 & $-0.821 * * *$ & 0.440 \\
\hline Store attributes & $-0.425^{* * *}$ & 0.654 & $-0.406 * * *$ & 0.666 & $-0.476 * * *$ & 0.621 \\
\hline Health & 0.176 & 1.192 & -0.021 & 0.979 & 0.066 & 1.069 \\
\hline $\begin{array}{l}\text { Environmental } \\
\text { concern }\end{array}$ & -0.182 & 0.834 & -0.005 & 0.995 & -0.154 & 0.857 \\
\hline $\begin{array}{l}\text { Easiness \& } \\
\text { Availability }\end{array}$ & $0.225^{* *}$ & 1.252 & $0.307 * * *$ & 1.359 & 0.131 & 1.140 \\
\hline $\begin{array}{l}\text { Pseudo R-square : C } \\
\text { Likelihood Ratio Te }\end{array}$ & $\begin{array}{l}\text { nd Snell (0 } \\
\text { Chi-square }\end{array}$ & $\begin{array}{l}\text { 2), Nagel } \\
33.981 \mathrm{df}\end{array}$ & $\begin{array}{l}\text { ke }(0.249) \\
1 \text { Sig }<0.0\end{array}$ & & & \\
\hline
\end{tabular}

vegetable at modern markets. Domicile was found to be significant in influencing consumer choice between going to all traditional retail formats and modern markets. The positive coefficient for domicile indicates that respondents who live in suburban and rural areas are more likely to choose all traditional retail formats over modern markets. The coefficient of income shows a significant and negative effect suggesting that consumers with lower income are more likely to shop at kiosks/warungs and peddlers.

In terms of variables extracted from factor analysis, there are six variables (i.e.,

\subsection{Determinants of consumers' choice}

According to the results from the logistic regression (Table 3), the socio-demographic and geographic factors (i.e., income, employment status of woman, education level, purchase frequency, and domicile) are found to have a statistically significant effect in determining the vegetable retail formats choice. Meanwhile, the other variables namely age, gender, marital status, and household size do not appear to be important in the choice between traditional and modern retail formats for vegetable purchasing.

The employment status of woman in the household and purchase frequency variable significantly affected consumer choice only between modern markets and peddlers, but not significant in explaining consumer choice between wet market and modern market or kiosks/warungs and modern market. The positive value for purchase frequency and negative sign for employment status of woman suggests that unemployed women (housewife) and purchase vegetable more frequently are more likely to choose peddlers over modern markets. The coefficient of education level was found negative and significant in explaining consumer choice between kiosks/warungs and modern market. It means that well-educated respondents are more likely to purchase product quality, food safety concern, brand \& traceability, store attributes, price, and easiness \& availability) are statistically significant and relevant to determine the consumers' retail format choice for vegetable purchasing. Meanwhile, environmental concern and health motives did not show significant effect in explaining consumer choice between modern markets and all traditional retail formats.

The coefficient of product quality is positive in the equation between modern markets and kiosks/warungs suggesting that respondents who rate product quality as an important factor are more likely to shop at kiosks/warungs. Price shows a positive and significant effect between all traditional retail formats and modern markets indicates that consumers who prefer to get cheaper price are more likely to shop at all traditional retail formats. According to Goldman et al.(1999), traditional retail formats tend to be perceived as offering superior quality, especially freshness, and lower price. Vegetables in traditional retail formats are perceived fresher by consumers because they usually directly delivered from farmer or wholesaler markets.

Food safety concern is positively significant suggesting that consumers who are concerned about food safety would be likely to shop at wet markets and peddlers. There are different findings from previous study regarding food safety. Some research found 
that consumers perceive fresh products are safer in modern markets (Maruyama and $\mathrm{Wu}$, 2014), while others suggested that fresh products are safer in traditional retail formats (Irianto, 2013).

Store attributes are negative, indicating that consumers and who rate this variables as an importance factors are more likely to purchase vegetable at modern markets. Regarding store attributes, modern markets have competitive advantage by providing a clean environment and superior comfort for shoppers (Suryadarma et al., 2010), more practical to shop and packaging (Farhangmehr et al., 2001; Kusumawaty et al., 2013), and more secure and safety of marketplace (Irianto, 2013; Rozhan et al., 2013).The convenience of shopping from modern retail outlets can be described such as near home/work place, easy parking, trolleys and baskets facilities, everything in one roof, extended trading hours, and good display of products (Chamhuri and Batt, 2013; Geuens et al., 2003). Besides store attributes, modern formats consumers also look brand \& traceability due to the negative sign in the equation when deciding to purchase vegetables and fruits. In previous study, Rozhan et al., (2013) found that product information, product label and brand are very important to consumers and this will help them to make a decision in selecting the preferred vegetables and fruits.

The coefficient of easiness \& availability is positive suggesting that consumers who are concerned about easiness and availability would likely to choose kiosks/warungs and wet markets. Due to the location of modern markets are often outside of residential area and requires more travel time, consumers are prefer to shop at traditional outlets that close to their house (Maruyama and Wu, 2014).

\section{CONCLUSSIONS}

The findings indicated that traditional retail formats are still used most frequently by the majority of consumers who are reside in suburban and rural area, mostly lower in education and income, as housewife (unemployed) and purchase vegetable almost every day. Quality, safety, price, easiness \& availability were influential factors for consumers to shop at traditional market. Meanwhile, modern markets meet the needs of higher income, well-educated and employed women who are reside in urban area and have concerned on store attributes and brand \& traceability information.

\section{REFERENCES}

Briz, T. and Ward, R.W. (2009), "Consumer awareness of organic products in Spain: An application of multinominal logit models”, Food Policy, Elsevier Ltd, Vol. 34 No. 3, pp. 295-304.

Chamhuri, N., Batt, P.J. (2013), "Segmentation of Malaysian shoppers by store choice behaviour in their purchase of fresh meat and fresh produce", Journal of Retailing and Consumer Services, Elsevier, Vol. 20 No. 6, pp. 516-528.

Dyck, J., Woolverton, A.E., Rangkuti, F.Y. (2012,June), “Indonesia ’s Modern Retail Sector Interaction With Changing Food Consumption and Trade Patterns”, U.S. Department of Agriculture, Economic Research Service, No. 97.

Farhangmehr, M., Marques, S., Silva, J. (2001), "Hypermarkets versus traditional retail stores - consumers' and retailers' perspectives in Braga: a case study", Journal of Retailing and Consumer Services, Vol. 8 No. 4, pp. 189-198.

Geuens, M., Brengman, M., S’Jegers, R. (2003), "Food retailing, now and in the future. A consumer perspective", Journal of Retailing and Consumer Services, Vol. 10 No. 4, pp. 241-251.

Goktolga, Z.G., Bal, S.G. and Karkacier, O. (2006), "Factors effecting primary choice of consumers in food purchasing: The Turkey case”, Food Control, Vol. 17 No. 11, pp. 884-889.

Goldman, A. (2001), “The transfer of retail formats into developing economies: The example of China”, Journal of Retailing, Vol. 77 No. 2, pp. 221-242.

Goldman, A., Hino, H. (2005), “Supermarkets vs. traditional retail stores: diagnosing the barriers to supermarkets' market share growth in an ethnic minority community", Journal of Retailing and Consumer Services, Vol. 12 No. 4, pp. 273-284.

Goldman, A., Krider, R., Ramaswami, S. (1999), "The Persistent Competitive Advantage of Traditional Food Retailers in Asia: Wet Markets’ Continued Dominance 
in Hong Kong”, Journal of

Macromarketing , Vol. 19 No. 2 , pp. 126139.

Greene, W.H. (1998), LIMDEP: A User's Manual, Econometric Software, Inc., New York.

Irianto, B. (2013), “Traditional versus modern markets in Indonesia: A case study for horticultural produce marketing in Kota Batu Traditional Market, East Java Province”, Acta Horticulturae, Vol. 1006, pp. 165-170.

Janssen, M. and Hamm, U. (2012), "Product labelling in the market for organic food: Consumer preferences and willingness-topay for different organic certification logos", Food Quality and Preference, Elsevier Ltd, Vol. 25 No. 1, pp. 9-22.

Kohansal, M.R. and Firoozzare, A. (2013), "Applying multinomial logit model for determining socio-economic factors affecting major choice of consumers in food purchasing: The case of Mashhad", Journal of Agricultural Science and Technology, Vol. 15 No. SUPPL, pp. 1307-1317.

Kusumawaty, Y., Batt, P.J., Chamhuri, N., Storer, C.E. (2013), "Fresh fruit and vegetable purchasing patterns among traditional and modern retail stores in Riau, Indonesia”, Acta Horticulturae, Vol. 1006, pp. 193-202.

Maruyama, M., Trung, L.V. (2007), "Supermarkets in Vietnam: Opportunities and obstacles", Asian Economic Journal, Vol. 21 No. 1, pp. 19-46.

Maruyama, M., Wu, L. (2014), “Quantifying barriers impeding the diffusion of supermarkets in China: The role of shopping habits", Journal of Retailing and Consumer Services, Elsevier, Vol. 21 No. 3, pp. 383-393.

Reardon, T., Berdegué, J.A. (2008), The Retail-Led Transformation of Agrifood Systems and its Implications 1 for Development Policies, World Development Report 2008, World Bank.

Rozhan, A.D., Mohd Hafizuddin, Z., Noorlidawati, A.H. (2013), "Marketing channels for fresh vegetables and fruits in Malaysia”, Acta Horticulturae, Vol. 1012, pp. 1371-1378.

Suryadarma, D., Poesoro, A., Akhmadi, Budiyati, S., Rosfadhila, M., Suryahadi, A. (2010), "Traditional food traders in developing countries and competition from supermarkets: Evidence from Indonesia", Food Policy, Elsevier Ltd, Vol. 35 No. 1, pp. 79-86.

Tiryaki, G.Y. and Akbay, C. (2010), “Consumers' fluid milk consumption behaviors in TURKEY: an application of multinomial logit model.”, Quality \& Quantity, Vol. 44 No. 1, pp. 87-98.

Tobler, C., Visschers, V.H.M. and Siegrist, M. (2011), "Eating green. Consumers' willingness to adopt ecological food consumption behaviors", Appetite, Elsevier Ltd, Vol. 57 No. 3, pp. 674-682. 